\title{
Associations between teacher self-efficacy and the use of Objective Structured Clinical Examination in medical education
}

\section{Associações entre a autoeficácia docente e a utilização do Objective Structured Clinical Examination na educação médica}

Rebeca Carvalho Bressa' (D) | rebecabressa@gmail.com

Camélia Santina Murgo' (1D) camelia@unoeste.br

Bárbara Cristina Soares Sena² (D) barbara_kristina08@hotmail.com

\begin{abstract}
Introduction: The inclusion of new methodologies and assessments in the medical education area has indicated the need to understand teachers' perception of their own ability to use them adequately.

Objective: Thus, the present study aimed to investigate possible associations between teacher self-efficacy and the use of OSCE.

Method: The Teacher Self-efficacy Scale and Self-Efficacy Sources Scale and a characterization questionnaire were used. Forty-seven medical teachers from a private university, of both genders, aged between 31 and 78 years, participated in the study.

Results: The results indicated that the factors Social Persuasion and Vicarious Learning were the most endorsed, suggesting that these sources are the ones that interfere the most in the formation of the participants' beliefs. There was only one positive and statistically significant correlation, with a weak magnitude, established between the Intentionality of Action Efficacy and Vicarious Learning. The other identified correlations were statistically negative and of moderate magnitude.

Conclusions: The teachers who agreed with some important characteristics about the OSCE method also showed higher levels of self-efficacy. Therefore, professionals with greater perseverance, resilience and confidence, have also been more committed to teaching, research and student assistance.
\end{abstract}

Keywords: Teacher Self-Efficacy; Medical Education; OSCE.

\section{RESUMO}

Introdução: A inserção de novas metodologias e avaliações na área da educação médica tem indicado a necessidade de compreender a percepção dos docentes sobre sua própria capacidade de utilizá-las adequadamente.

Objetivo: Com base nisso, este estudo buscou investigar as possíveis associações entre a autoeficácia docente e o uso do OSCE.

Método: Utilizaram-se a Escala de Autoeficácia do Professor, a Escala sobre Fontes de Autoeficácia e um questionário de caracterização. Participaram 47 docentes de Medicina de uma universidade privada, de ambos os sexos, com idade entre 31 e 78 anos.

Resultados: Os resultados indicaram que os fatores persuasão social e aprendizagem vicária foram os mais endossados, sugerindo que essas fontes são as de maior interferência na formação de crenças dos participantes. Houve apenas uma correlação positiva e com significância estatística, com magnitude fraca, estabelecida entre eficácia na intencionalidade da ação e aprendizagem vicária. As demais correlações encontradas se demonstraram estatisticamente em sentido negativo e com magnitudes moderadas.

Conclusões: Os docentes concordantes com algumas características importantes sobre o método OSCE apresentaram maiores níveis de autoeficácia, e isso significa que os profissionais com alto nível de perseverança, superação, confiança e resiliência são mais comprometidos com o ensino, a pesquisa e a assistência estudantil.

Palavras-chave: Autoeficácia Docente; Educação Médica; OSCE.

1 Universidade do Oeste Paulista, Presidente Prudente, São Paulo, Brazil.

${ }^{2}$ Universidade Federal de São Carlos, São Carlos, São Paulo, Brazil.

Chief editor: Daniela Chiesa

Associate editor: Roberto Zonato Esteves

Received on 05/01/20; Accepted on 11/02/20.

Evaluated by the double blind review process. 


\section{INTRODUCTION}

Since the end of the $20^{\text {th }}$ century, medical education has been constantly evolving, which has led to changes and updates in the area over the years. Around 1910, the Flexner Report tried to establish norms and guidelines for medical education in the United States and Canada and the Flexnerian paradigm has been recognized and used as the basis for worldwide medical education. However, over the years, the model ended up being seen as synonymous with a mechanistic, biologistic, individualist, specialistic and technical medical education'.

At the end of the twentieth century, these criticisms and discussions led Medicine to get closer to collective health ${ }^{2}$. Then, in 1970, a new model emerged, known as the Integral Medicine paradigm, which was reinforced at the International Conference of the World Health Organization, in Alma-Ata, in 1978. After that, the concept of community medicine and its importance in the health-disease process triggered changes in the way of teaching and exercising the profession. The trained physicians would start to meet social expectations, have more specific skills such as communication techniques and leadership positions, in addition to being generalists and knowing Primary Health Care $^{3,4}$.

In addition to the paradigm changes, medical education undergoes modifications in the teaching and learning process, which corroborates with new concepts seen in the area of overall education. "In the educational context, at present one hardly talks about stimulus anymore [...]. Currently, the catchphrases are significant learning, conceptual change and studentcentered teaching" ${ }^{\prime \prime}$. The students become autonomous in their learning and new methodologies try to help them build their own ways to reach their cognitive potential ${ }^{6}$.

Considering these factors and the need for practical training in the medical field, since the 1960s new methodologies at different universities around the world have put the student at the center of the learning process ${ }^{7}$. Aiming to meet this demand, the inclusion of a set of educational innovations has been initiated, such as simulation, which has been highlighted mainly in the medical field, as technological and didactic devices that help the teaching-learning process ${ }^{8}$.

In this regard, it is worth clarifying that there are several types of simulators and simulations, from the simpler mannequins to robots that simulate specific and high-fidelity realistic situations ${ }^{9,10}$. In the simulation, a problem-situation can be created with standardized actors or patients, which allows evaluating specific tasks in several areas. With this flexibility, the simulation can come close to real-life and guarantee the student's observation in a safe environment, where the error can be practiced and contribute to significant learning without harming the patient ${ }^{11}$.

The assessment of clinical skills is, as well as practical and meaningful teaching, a necessity in current medical education, as it seeks to verify the efficacy of learning in the professional act and the most active pedagogical technologies and instruments can assist in the training of future professionals ${ }^{12}$. Accordingly, Miller's Pyramid is the most often used instrument in medical education to help the teacher to not be restricted to theoretical knowledge alone, and to develop the "know-how" in the assessment of competences and skills ${ }^{13}$.

Thinking about the development of these qualifications, the OSCE (Objective Structured Clinical Examination) methodology can better guide this "know how to demonstrate" that the medical student needs to perform during the course. Simulation and feedback help teachers to build together with students the necessary professional knowledge and skills in a joint and more simultaneous manner ${ }^{14}$. The OSCE is one of the best and most reliable methods of assessing competences in medical education. The first experience of this method was described in 1975 and, since then, the OSCE has been one of the most widespread evaluation methods worldwide. It is standardized and structured, allowing students to learn from their mistakes and successes throughout the learning process and, therefore, it is considered a formative assessment ${ }^{15,16}$.

The teachers-examiners in the OSCE method constitute a fundamental element of learning, as they are responsible, according to their specialty, to check the ability, competence and correct imperfections in the students' work process ${ }^{17}$. Several elements can contribute to the effectiveness of this type of evaluation, not only the technical knowledge of the method, but also the belief of the teacher who performs it. Therefore, as advocated by Bandura ${ }^{18}$, thoughts, feelings and beliefs interfere with the way a person will behave when facing a certain action.

In the educational context, specifically, one can consider the teacher self-efficacy beliefs, which is the teachers'judgment about their own ability to organize and achieve their students involvement and learning, in a significant way, even in the face of the diversity found in the classroom ${ }^{19}$. These beliefs are composed of four sources of training, namely direct experience, vicarious learning, social persuasion and physical and emotional state ${ }^{20,21}$. Direct or mastery experience is the most effective source for the creation of a strong sense of self-efficacy, as it is directly related to the successes obtained with one's expertise and personal experience ${ }^{22}$. Vicarious experiences refer to the observation of social models with which the individual identifies. Social persuasion, in turn, occurs through feedbacks received by people who have credibility for the other, therefore, the subjects tend to use examples and listen, in a more significant way, to other individuals who are important and reliable for them. And finally, the physiological 
states that constitute the physical and emotional reactions to pressures such as, for instance, sweating, stomach pain, anxiety, and stress, among others ${ }^{22}$.

In this situation, verifying self-efficacy beliefs can contribute to the understanding of the teaching activity when carrying out the OSCE and its association with significant learning. Understanding the teacher's beliefs and how it interferes with the OSCE application can contribute to the exercise of teaching and the current transformations that medical education has undergone.

When correlating student behavior to their performance, the teacher cannot disregard the emotional dimension in the teaching-learning process ${ }^{23}$. And, consequently, the teachers must also evaluate themselves, as human relations are not one-sided. It is necessary to stimulate a reflective culture of the teaching action, assessing the personal structure of this professional, their feelings and desires and, mainly, their beliefs ${ }^{24,25}$, aiming to strengthen pedagogical processes such as the OSCE. The greater the teachers' perception and understanding of their educational practices, their feelings and beliefs, the more easily they will avoid reactions that can potentiate anguish and impair their role as educators ${ }^{26}$.

According to laochite ${ }^{27}$ "[...] as important as for future teachers to acquire the skills, competences and knowledge necessary for teaching, is that they believe they will be able to exercise their roles as teachers with some success". An important aspect to be clarified, when discussing teacher self-efficacy, concerns the role of self-efficacy beliefs in the performance of this professional. "These beliefs influence whether people think pessimistically or optimistically and in ways that help or hinder the individual"28.

With all that has been exposed, one can consider that self-efficacy beliefs can interfere in the teaching-learning process not only when associated with student learning but also related to teacher action. Therefore, only teachers who constantly reflect on their pedagogical actions, evaluate, monitor and regulate their self-efficacy beliefs are able to trigger a significant learning process in their students ${ }^{19}$. Additionally, a teacher with a higher perception of self-efficacy may demonstrate greater acceptance and better use of training techniques and instruments, such as the use of the OSCE as an evaluation process in medical education.

As for the studies that sought to identify and associate the self-efficacy of the medical teacher, these are scarce in the literature. What is indicated is that being exposed to good teachers can improve the understanding of knowledge and the clinical performance of medical students. Still, few studies have been dedicated to the understanding of the psychological mechanisms related to teaching practice ${ }^{29}$. Therefore, according to Dybowski, Sehner and Harendza ${ }^{29}$, the quality of teaching can benefit from teachers who are self-effective and capable of detecting and promoting the students' competences.

Thus, the overall objective of this study is to analyze the association between teacher self-efficacy and the effectiveness in the application of OSCE as an instrument of formative assessment. Therefore, the associations of selfefficacy concerning classroom management and the teacher's intentionality of action were verified, and the associations between the application of OSCE and the teachers' self-efficacy beliefs were identified.

\section{METHOD}

\section{Participants}

Forty-seven teachers of the medical course of a private University in the countryside of the state of São Paulo participated in this study, of which $55.3 \%(n=26)$ were males and $44.7 \%$ females $(n=21)$, with age varying between 31 and 78 years $(M=44.62$; $S D=10.35)$. It is important to highlight that, of these professionals, $91.5 \%(n=43)$ are physicians and $8.5 \%(n=4)$ are nurses. As for the time of experience as teachers, it ranged between 1 and 35 years, with an average of $11.5(\mathrm{M}=11.51$; $\mathrm{SD}=7.70)$ years working as teachers. Regarding the degree, $63.8 \%(n=30)$ declared they have the Lato Sensu Postgraduate Degree (specialization), whereas a smaller number had a Stricto Sensu Postgraduate Degree, which prepares the student to pursue a career in Academia and are divided between those who have a Master's Degree $(29,8 \% ; n=14)$ and a Ph.D. $(6.4 \% ; n=3)$.

Finally, regarding the area of expertise/specialty, most of them were from the area of Internal Medicine $(31.9 \%$; $n=$ 15), followed by Emergency Care (19.1\%; $n=9)$, Surgical Clinic $(14,9 \%, n=7)$, Public Health and Pediatrics $(12.8 \%, n=6$ in each) and the lowest frequency of participants was found in the Gynecology and Obstetrics area $(8.5 \%, n=4)$.

\section{Instruments}

The following instruments were used for data collection:

A. Teacher Self-Efficacy Scale (TSES) ${ }^{30}$ : it is an adaptation of the Ohio State Teacher Efficacy Scale ${ }^{31}$ and evaluates the teacher self-efficacy in relation to classroom management and the teacher's intentionality of action. The scale has two factors (subscales), namely Factor 1 (Teacher's intentionality of action), which represents the teacher's capacity to mobilize the students to carry out their tasks and teaching mediation (a $=0.87$ ); and Factor 2 (classroom management efficacy), which is related to the teacher's belief to manage and deal with the multiple aspects of the class routine $(a=0.76)$. The reliability of the total scale was 0.91 (alpha). 
B. Self-Efficacy Sources Scale (SESS) ${ }^{27}$ : it assesses the interference of the four sources of self-efficacy belief formation. This instrument consists of items that refer to the four sources of elf-efficacy (SE) proposed by Bandura ${ }^{32}$. The items represent the sources of direct experience $(5,12$ and $13 ; a=0.36$ ); vicarious experience $(1,2$ and $6 ; a=0.54)$; of expression to social persuasion $(3,10,11,14$ and $15 ; a=0.62)$; and finally, of physiological and affective states $(4,7,8,9$ and $16 ; a=0.82)$. The reliability of the total scale was 0.83 (alpha).

C. Participant Characterization Questionnaire (PCQ): in this instrument, in addition to the sociodemographic description, assertive questions were included regarding the main characteristics of simulation activities, such as the OSCE, according to the systematic review by Issenberg, Mcgaghie, Petrusa, Gordon and Scalese ${ }^{33}$ and the respective teacher perceptions of the subject and the work context. The PCQ consisted of 26 questions, with the first ten being related to sociodemographic data, the participant's training and area of activity, and the other sixteen questions were structured as a Likert-type scale (5 points), ranging from "I totally disagree" to "I totally agree". The instrument is divided between the factors Teacher well-being $(a=0.68)$ and Main characteristics $(a=0.73)$ and the reliability of the total scale was 0.81 (Cronbach's alpha).

\section{Data analysis}

The data were analyzed using the Statistical Package for the Social Sciences (SPSS) v.21 software with descriptive statistics to characterize the sample and the participants' means in the instruments. Subsequently, inferential statistics with Pearson's correlation between the factors of the instruments were performed. For the interpretation of correlational data, Dancey and Reid ${ }^{34}$ parameters were used, in which correlation coefficients with a value equal to 0 are considered null, between 0.10 and 0.30 are considered weak, from 0.40 and up to 0.60 moderate, from 0.70 to 0.90 strong and correlations equal to 1 are considered perfect. Moreover, analyses of the reliability indices of the scale factors were performed using Cronbach's alpha for this study sample.

\section{RESULTS}

Aiming to analyze the association between teacher self-efficacy and effectiveness in the application of the OSCE as a formative evaluation instrument, descriptive statistics of the scores obtained at the Participant Characterization Questionnaire (PCQ) instrument, the statements that were directed to teacher perception about the context and about the OSCE, in a subdivision of the PCQ: Teacher Perception about Context (TPCONTEXT) and the Teacher Perception about the OSCE (TPOSCE) were initially employed.

Descriptive statistics were also performed, considering the mean scores in the factors of the Teacher Self-Efficacy Scale (TSES), the Self-Efficacy Sources Scale (SESS) and the Participant Characterization Questionnaire (PCQ), subdivision: TPCONTEXT and TPOSCE.

According to Table 1, in TSES, the highest means were related to the factor Intentionality of Action Efficacy, which has already been demonstrated in other studies such as the one by laochite ${ }^{27}$ and Rocha ${ }^{35}$. In the SESS, the Social Persuasion factor was the most endorsed by the participants, obtaining the highest mean when compared to the other factors of the instruments, which may indicate that this source is the one with the greatest interference in the formation of teachers' beliefs.

The direct experience sources $(M=14.91)$ and vicarious learning ( $M=15.14)$ were the ones that the teachers showed the lowest means. The main hypothesis for these data is that the teachers of this $\mathrm{HEI}$ have little experience in the applicability of the OSCE, as it only started in July 2015 and became effective in all basic clinical areas only at the end of 2016. Although 27 teachers (57.4\%) have more than 10 years of teaching experience and 8 (17\%) more than 20 years, perhaps the fundamental practice subsidies in this type of assessment and in a more active learning methodology, have not yet been

Table 1. Descriptive statistics of the results of TSES, SESS and PCQ subdivision (TPCONTEXT, TPOSCE)

\begin{tabular}{|c|c|c|c|c|c|}
\hline Factors / Instrument & $\mathbf{N}$ & Minimum & Maximum & $\mathbf{M}$ & SD \\
\hline TPCONTEXT & 47 & 18 & 30 & 25.46 & 2.94 \\
\hline TPOSCE & 47 & 19 & 43 & 36.59 & 4.48 \\
\hline Classroom Management Efficacy & 47 & 37 & 60 & 48.93 & 5.25 \\
\hline Intentionality of Action Efficacy & 47 & 50 & 84 & 69.36 & 7.66 \\
\hline Direct Experience & 47 & 8 & 18 & 14.91 & 2.43 \\
\hline Vicarious Learning & 47 & 9 & 18 & 15.14 & 2.4 \\
\hline Social Persuasion & 47 & 14 & 30 & 25.51 & 3.61 \\
\hline Physiological states & 47 & 6 & 28 & 17.17 & 6.68 \\
\hline
\end{tabular}

Source: Study data. 
established in this group of professionals.

Subsequently, we sought to verify the correlations between the items of TPCONTEXT and TPOSCE with the Teacher Self-Efficacy Scale (TSES), as shown in the tables below.

Table 2. Correlations between Perception factors (TPCONTEXT AND TPOSCE) and the Teacher Self-Efficacy Scale (TSES)

\begin{tabular}{lll}
\hline \multicolumn{1}{c}{ TPCONTEXT: } & Efficacy in classroom management & Intentionality of action efficacy \\
\hline Q11 - Free expression of ideas & 0.01 & -0.03 \\
\hline Q12 - Support from colleagues & -0.26 & -0.22 \\
\hline Q13 - Feels prepared to teach & $0.41^{* *}$ & $0.40^{* *}$ \\
\hline \multicolumn{1}{c}{ TP14 - Is satisfied as a teacher } & 0.18 & 0.25 \\
\hline \multicolumn{1}{c}{ TOSC: } & $\mathbf{0 . 2}$ & $\mathbf{0 . 2 0}$ \\
\hline Q15-Feedback is important & & $0.29^{*}$ \\
\hline Q16-Systematic practice is essential for efficacy & 0.24 & 0.25 \\
\hline Q17-Promotes integration of disciplines & 0.2 & -0.02 \\
\hline Q18- Simulation difficulty is important & 0.02 & $0.29^{*}$ \\
\hline $\begin{array}{l}\text { Q19-It is more effective to develop and correct } \\
\text { skills than real practice alone }\end{array}$ & $0.43^{* *}$ & 0.16 \\
\hline $\begin{array}{l}\text { Q20-Controlled environment without adverse } \\
\text { consequences }\end{array}$ & 0.14 & -0.2 \\
\hline Q21-Prepares the student for professional practice & -0.22 & $0.34^{*}$ \\
\hline Q22-Student is active & 0.11 & -0.17 \\
\hline Q23-Specific goals and student masters the skill & -0.23 & -0.11 \\
\hline Q24- Provides significant learning & -0.12 & -0.17 \\
\hline $\begin{array}{l}\text { Q25-Provides greater security in the teaching } \\
\text { activity and greater efficacy in student learning }\end{array}$ & -0.13 & $0.27^{*}$ \\
\hline Q26-Provides conditions for teacher updating & 0.21 & 0.12 \\
\hline TOTAL & 0.23 & $\mathbf{0 . 1}$ \\
\hline
\end{tabular}

${ }^{*} \mathrm{p}<0.05 ;{ }^{* *} \mathrm{p}<0.01$

Source: Study data.

It can be observed that no significant total correlations were found for the TPCONTEXT and TPOSCE factors with any of the TSES factors. What can be observed are the associations of some statements, being isolated, in a positive sense and with a weak magnitude. Item Q13 (Feels prepared to teach), for instance, showed a positive significance with the two variables of AED (Classroom Management and Intentionality of Action).

Similarly, associations were also found between other items and variables, such as: item Q18 (Difficulty of simulation is important) showed positive significance with Classroom Management Efficacy; item Q21 (OSCE prepares the student for professional practice) is positively related to Intentionality of Action Efficacy; and item Q25 (OSCE provides greater security in the teaching activity and greater efficacy in student learning) with intentionality of action efficacy.

Subsequently, we tried to verify the association between Perception (TPCONTEXT and TPOSCE) and the Sources of Self- efficacy factors. Table 3 shows that no statistically significant correlations were found in relation to the sources of Direct Experience and Physiological and Affective States. As for the sources of Vicarious Learning and Social Persuasion, the correlations were statistically significant, in a positive sense and with a magnitude varying from weak to moderate.

The correlations between the isolated factors of TPCONTEXT and TPOSCE with the factors of the Self-efficacy Sources Scale were mostly null or showed no statistical significance. In relation to those that were statistically significant, these ranged from weak to moderate in magnitude and had a positive sense, except for item Q13 (Feels prepared to teach) and the factor Physiological and Affective States, in which the correlation was negative. This can mean that the more they feel prepared to teach, the less the source of physiological and affective states interferes in the formation of the teachers' beliefs in this studied group. 
Table 3. Correlations between Perception factors (TPCONTEXT AND TPOSCE) and the Self-Efficacy Sources Scale (SESS)

\begin{tabular}{|c|c|c|c|c|}
\hline TPCONTEXT: & Direct Experience & Vicarious Learning & Social Persuasion & $\begin{array}{l}\text { Physiological and } \\
\text { Affective States }\end{array}$ \\
\hline Q11 - Free expression of ideas & 0.17 & $0.30 *$ & 0.18 & 0.11 \\
\hline Q12 - Support from colleagues & -0.01 & -0.04 & -0.05 & 0.13 \\
\hline Q13- Feels prepared to teach & 0.05 & 0.11 & -0.06 & $-0.42^{* *}$ \\
\hline Q14- Is satisfied as a teacher & -0.01 & 0.16 & 0.16 & -0.15 \\
\hline TOTAL & 0.24 & $0.38 * *$ & $0.38 * *$ & -0.00 \\
\hline \multicolumn{5}{|l|}{ TPOSCE: } \\
\hline Q15- Feedback is important & 0 & $0.31 *$ & 0.24 & 0 \\
\hline $\begin{array}{l}\text { Q16- Systematic practice is essential } \\
\text { for efficacy }\end{array}$ & 0.1 & $0.39 * *$ & $0.49 * *$ & 0.22 \\
\hline Q17-Promotes integration of disciplines & -0.05 & -0.03 & -0.04 & -0.01 \\
\hline Q18- Simulation difficulty is important & 0.13 & $0.32 *$ & 0.27 & -0.01 \\
\hline $\begin{array}{l}\text { Q19-It is more effective to develop and } \\
\text { correct skills than real practice alone }\end{array}$ & 0.14 & $0.46 * *$ & $0.33^{*}$ & 0.1 \\
\hline $\begin{array}{l}\text { Q20-Controlled environment without } \\
\text { adverse consequences }\end{array}$ & 0.09 & -0.23 & 0 & $0.36 *$ \\
\hline $\begin{array}{l}\text { Q21-Prepares the student for } \\
\text { professional practice }\end{array}$ & $0.31 *$ & $0.51 * *$ & $0.41 * *$ & 0.27 \\
\hline Q22-Student is active & -0.04 & -0.09 & 0.13 & 0.24 \\
\hline $\begin{array}{l}\text { Q23-Specific goals and student masters } \\
\text { the skill }\end{array}$ & 0.02 & -0.15 & -0.15 & 0.13 \\
\hline Q24- Provides meaningful learning & 0.05 & -0.08 & 0.01 & 0.11 \\
\hline $\begin{array}{l}\text { Q25- Provides greater security in the } \\
\text { teaching activity and greater efficacy in } \\
\text { student learning }\end{array}$ & 0.3 & $0.37 * *$ & $0.51 * *$ & 0.1 \\
\hline $\begin{array}{l}\text { Q26-Provides conditions for teacher } \\
\text { updating }\end{array}$ & 0.26 & $0.36 *$ & $0.44 * *$ & 0.02 \\
\hline TOTAL & 0.11 & $0.29^{*}$ & $0.32^{*}$ & 0.28 \\
\hline
\end{tabular}

${ }^{* *} \mathrm{p}<0.01$

Source: Study data.

As for the identified positive associations according to the self-efficacy sources were, for instance, Vicarious Learning with items Q11 (Free expression of ideas), Q15 (Feedback is important), Q16 (Systematic practice is essential for efficacy), Q18 (Simulation difficulty is important), and Q19 (It is more effective for developing and correcting skills than real practice alone), among others. Social Persuasion with items Q16 (Systematic practice is essential for efficacy), Q19 (It is more effective for developing and correcting skills than real practice alone), Q21 (Prepares the student for professional practice), Q25 (Provides greater security in the teaching activity and greater efficacy in student learning) and Q26 (Provides conditions for teacher updating). And finally, the Direct Experience with Q21 (Prepares the student for professional practice) and Physiological and Affective States with: Q20 (Controlled environment without adverse consequences).

Finally, the association between the types of self-efficacy and the sources was assessed, as shown in Table 4.

Table 4. Correlations between factors of the Teacher Self-Efficacy Scale (TSES) and the Self-Efficacy Sources Scale (SESS)

\begin{tabular}{ccccc}
\hline & Direct Experience & Vicarious Learning & Social Persuasion & $\begin{array}{c}\text { Physiological and } \\
\text { Affective States }\end{array}$ \\
\hline Efficacy in Classroom Management & -0.11 & 0.26 & 0.02 & $-0.42^{* *}$ \\
\hline Intentionality of Action Efficacy & -0.07 & $0.32^{*}$ & 0.04 & $-0.40^{* *}$ \\
\hline
\end{tabular}

${ }^{*} \mathrm{p}<0.05 ;{ }^{* *} \mathrm{p}<0.01$

Source: Study data. 
Most of the correlations were null or without statistical significance. Regarding the statistically significant correlations, these were negative and showed moderate magnitudes between the factors of Self-efficacy and the Physiological and Affective States sources, indicating that the greater the belief in the ability to teach or control the academic environment, the lower the influences of physiological and emotional pressures on the performance and formation of these beliefs. There was only one positive and statistically significant correlation, of weak magnitude, which was established between Intentionality of Action Efficacy and Vicarious Learning, suggesting that teachers who believe in their capacity to mobilize students for the teaching-learning process may have these beliefs formed from their own experiences in the classroom or from the experiences of their training process as a whole.

\section{DISCUSSION}

Initially, the data indicate the importance of the Intentionality of Action Efficacy on the teachers' sense of self-efficacy, information that corroborates other studies that have been previously carried out ${ }^{27,35}$. As observed by Polydoro, Winterstein, Azzi, Carmo and Venditti ${ }^{30}$ in the national adaptation of the Ohio State Teacher Efficacy Scale ${ }^{31}$ instrument, the Intentionality of Action represents the teacher's belief in their capacity to mediate teaching and mobilize the student to perform the activities. Therefore, it is related to how teachers can help their students to value the teaching/learning process and encompass the actions of monitoring, encouraging, valuing, and providing feedback during the learning process.

Another source that was highlighted about the teachers' appraisal of their own capacities was Social Persuasion, which was analyzed as the source of greatest interference. According to Bandura ${ }^{32}$, social persuasion is one of the most prevalent sources in new teachers and, in this group, there is also a high percentage of teachers without any experience in the professional activity, considering that 20 (42.6\%) had less than 10 years of teaching activity and, of the latter, $10(21.3 \%)$ had less than 5 years of experience.

Still from this perspective, social persuasion is one of the most distant sources for strengthening $\mathrm{SE}$, as it can be limited regarding the scope of personal belief in a longlasting manner. But it can reinforce self-assessment, if there is a positive appreciation that the incentive is within the limits of reality ${ }^{21}$. Supposedly, the teachers participating in this research are being encouraged by the $\mathrm{HEl}$ but have not yet acquired the experience or pedagogical and scientific knowledge of the formative evaluation method to adequately strengthen their beliefs. Thus, as stated by Bandura ${ }^{32}$, the simple verbal note about someone's capacity is not enough, as it is also necessary for the environment to provide experiences that corroborate the efficacy over a period of time.

Regarding the associations between the professional performance factors and the perception of self-efficacy, it was observed that, if you feel prepared to exercise your activity, you will increase your belief in the capacity to manage the classroom and will maintain your intentionality of action. In other words, feeling prepared to exercise the teaching practice strengthens the teacher's beliefs in managing daily life in the classroom and mobilizing the students to perform their tasks. Bandura $^{32}$ explains, according to the Social Cognitive Theory, that personal interest is developed because of affective selfreactions and the SE mechanisms. Thus, people maintain a permanent interest in tasks or activities for which they feel capable, effective and satisfied.

Associations between self-efficacy and the use of OSCE in the teaching practice were also identified. Therefore, when perceiving simulation as an important part of the students training and preparation, as well as providing greater security at the time of teaching, the medical teacher has a positive increase in the efficacy of the intentionality of his action in the classroom. These data may indicate some possible associations between the use of OSCE and self-efficacy, as it demonstrates, for instance, that the teacher who feels capable of handling and managing everyday life in the classroom believes that the difficulty of the simulation can be an important variable for student learning in an OSCE clinical setting. It also shows that, presumably, teachers who have strong beliefs in their ability to mobilize students to perform tasks and in their teaching activities also believe that the OSCE prepares students for professional practice. Moreover, it also points out that teachers who mobilize students to perform tasks and for teaching activities believe that the OSCE provides greater security for the teachers' work and greater efficacy in student learning.

Regarding the feeling of being prepared to teach and to use the OSCE, correlations were identified, albeit negative, with the teachers' physiological and emotional states. Emotional physical states such as stress, fatigue, anxiety, tension, pain and the mood states are manifestations that can interfere with the perception of self-efficacy. This occurs because these feelings directly affect the person's judgment of their own ability to perform a task ${ }^{21}$. The control of these feelings and dealing with them is an important condition to be successful, contributing to strengthen self-efficacy beliefs ${ }^{36}$. Therefore, there is a decrease in these states when the teacher's perception of being prepared is strengthened.

As indicated in the results, positive associations were also found between the other sources of self-efficacy (vicarious learning, social persuasion and direct experiences) 
with everyday factors of medical education (use of systematic practices, simulation as an effective means of developing and correcting skills, students' preparation for medical practice, among others). With these associations, it can be observed that some characteristics of the OSCE are repeated and are important, mainly in the sources with positive statistical significance. These characteristics (importance of feedback and systematization, effective in correcting skills, greater security, teacher updating and preparation for professional practice) are consistent with the recommendations of Khan, Ramachandran, Gaunt and Pushkar ${ }^{37}$ about the OSCE. The authors describe that, although the technique can assess the three learning domains (cognitive, affective and psychomotor), it is not possible to test all levels of difficulty in each domain while using a single OSCE. The OSCE should be designed to assess certain competences or skills that cannot be assessed using pen and paper or tests based on computed methods ${ }^{37}$.

At the national level, other studies that used the same instruments as this study, showed a tendency towards medium and, often, high levels of teacher self-efficacy among higher education teachers ${ }^{27,35,38}$. The hypotheses that justify the fact that the teaching group of the present study obtained a more median level of self-efficacy must be confirmed with new studies and qualitative analyses, which will address the specificities of medical teaching and with the use of techniques such as the OSCE.

Regarding the means in the TSES subscales, a higher mean can be seen in the Teacher Intentionality of Action Factor, when compared to the Classroom Management Factor. This difference was also found in the studies carried out by laochite ${ }^{27}$ and Rocha ${ }^{35}$. Dybowski, Sehner and Harendza ${ }^{29}$ also used their own self-efficacy scale developed in their studies and the results imply that the quality of teaching can benefit from teacher training, the capacity to detect their students' competences and the improvement of self-efficacy in medical education.

As postulated byBandura and confirmed by several studies, the main sources of self-efficacy are direct experiences, vicarious experiences, social persuasion and subjective interpretation of physiological and affective states during an action ${ }^{32,21,22}$. According to Dybowski, Sehner and Harendza ${ }^{29}$, teacher training should be based on these principles to effectively improve the self-efficacy of medical education. Progress assessments such as the OSCE can be more reliable to assess teaching quality and clarify the association between teaching motivation, teaching self-efficacy and quality of clinical teaching.

\section{CONCLUSIONS}

The present study aimed to analyze the association between teacher self-efficacy and the effectiveness in the application of OSCE as an instrument of formative assessment. The study found a higher number of teachers with medium and low self-efficacy and the most prevalent source of efficacy was verbal persuasion, which needs to be confirmed with new qualitative approaches such as a focal group, interview or even an ethnographic study. Trends that also need to be studied and confirmed in further studies with a greater number of teachers and in different institutions were evidenced.

Nevertheless, the data indicate important points to be considered, such as the main observation made, that teachers who agree with some important characteristics about the OSCE method also showed higher levels of selfefficacy. Therefore, they are the professionals with greater perseverance, strategies to overcome difficulties, confidence and resilience, essential qualities for a teacher committed to teaching, research and assistance. As for the study limitations, the small sample size stands out, and therefore, future investigations that expand the sample to different contexts and medical schools are recommended. Moreover, studies with a larger sample would allow the use of other approaches to describe the association between the constructs, such as the theory of response to the multidimensional item included in the structural equation modeling.

This investigation aims to contribute to the dissemination of the self-efficacy construct in medical teaching and to strengthen the OSCE technique as meaningful learning. Therefore, the evaluation can stop being a "payback" to becoming an effective learning opportunity, different from pure mechanical learning. To persistently review the teaching work process and instrumentalize the teacher with the seriousness of methods such as the OSCE and constructs such as self-efficacy will make the training of a medical professional more in line with current social needs and more humanistic.

\section{AUTHORS 'CONTRIBUTION}

Rebeca Carvalho Bressa and Camélia Santina Murgo planned and carried out the project and data collection and wrote the result and discussion sections. Bárbara Cristina Soares Sena wrote the introduction section and made the necessary reviews. All authors contributed to the writing of the manuscript.

\section{CONFLICTS OF INTEREST}

We declare no potential conflicts of interest that could influence the publication process.

\section{SOURCES OF FUNDING}

None to be declared. 


\section{REFERENCES}

1. Amore Filho ED. Ações para a retomada do ensino da humanização nas escolas de medicina: uma revisão sistemática da literatura, 2010-2016 [dissertation]. Belo Horizonte: Universidade José do Rosário Vellano; 2018 [access in 20 oct. 2019]. Available from: http://tede2.unifenas.br:8080/ jspui/handle/jspui/200.

2. Mota A, Schraiber LB, Ayres JRCM. Desenvolvimentismo e preventivismo nas raízes da saúde coletiva: reformas do ensino e criação de escolas médicas e departamentos de medicina preventiva no estado de São Paulo (1948-1967). Interface Comum Saúde Educ. 2018;22(65):337-48. doi: 10.1590/1807-57622017.0810.

3. Torres ACS. Formação médica para a APS: percepções de egressos da UFC [dissertation]. Fortaleza: Universidade Federal do Ceará; 2016 [access in 8 dec. 2019]. Available from: http://www.repositorio.ufc.br/handle/ riufc $/ 22543$.

4. Rocha VXM. Reformas na educação médica no Brasil: estudo comparativo entre as diretrizes curriculares nacionais dos cursos de graduação em medicina de 2001 e 2014 [dissertation]. Santos: Universidade Católica de Santos; 2017 [access in 8 dec. 2019]. Available from: http://biblioteca. unisantos.br:8181/handle/tede/4441.

5. Moreira MA. Aprendizagem significativa: um conceito subjacente. Aprendizagem Significativa em Revista. 2011;1(3):25-46 [access in 20 oct. 2019]. Available from: http://www.if.ufrgs.br/asr/artigos/Artigo_ID16/ v1_n3_a2011.pdf.

6. Winters JRF. Tecnologias de informação e comunicação (TICs) na graduação em enfermagem: possibilidades e limites na formação de profissionais críticos-criativos e reflexivos [thesis]. Florianópolis: Universidade Federal de Santa Catarina; 2018 [access in 20 oct. 2014]. Available from: http:// joinville.ifsc.edu.br/ bibliotecajoi/arquivos/thesiss/201312.pdf.

7. Conterno SFR, Lopes RE. Pressupostos pedagógicos das atuais propostas de formação superiorem saúdeno Brasil:origens históricas efundamentosteóricos. Avaliação. 2016;21(3):993-1016. doi: 10.1590/S1414-40772016000300016.

8. Gomez MV, Vieira JE, Scalabrini-Neto A. Análise do perfil do professor da área da saúde que usam a simulação como estratégia didática. Rev Bras Educ Med. 2011;35(2):157-62. doi: 10.1590/S0100-55022011000200003.

9. Ferreira C, Carvalho JM, Carvalho FLQ. Impacto da metodologia de simulação realística, enquanto tecnologia aplicada a educação nos cursos de saúde. STAES, III Seminário de Tecnologias Aplicadas em Educação e Saúde; 8-9 maio 2017; Salvador, Brasil. Salvador: Uneb; 2017. p. 32-40.

10. Kaneko RMU, Lopes MHBM. Cenário em simulação realística em saúde: o que é relevante para a sua elaboração? Rev Esc Enferm USP. 2019:53:e03453. doi: 10.1590/s1980-220x2018015703453.

11. Negri EC, Mazzo A, Martins JCA, Pereira Junior GA, Almeida RGS, Pedersoli CE. Simulação clínica com dramatização: ganhos percebidos por estudantes e profissionais de saúde. Rev Latino-Am Enferm. 2017;25:e2916. doi: 10.1590/1518-8345.1807.2916.

12. Zimmermann MH, Silveira RMCF, Gomes RZ. O professor e a arte de avaliar no ensino médico de uma universidade no Brasil. Rev Bras Educ Med. 2019:43(3):5-15. doi: 10.1590/1981-52712015v43n3rb20180167.

13. Amaral $E$, Domingues $\mathrm{RCL}$, Bicudo-Zeferino AM. Avaliando competência clínica: o método de avaliação estruturada observacional. Rev Bras Educ Med. 2007;31(3):287-90. doi: 10.1590/S0100-55022007000300011.

14. Franco CAGS, Franco RS, Santos VM, Uiema LA, Mendonça NB, Casanova AP, et al. OSCE para competências de comunicação clínica e profissionalismo: relato de experiência e meta-avaliação. Rev Bras Educ Med. 2015;39(3):433-41. doi: 10.1590/1981-52712015v39n3e02832014.

15. Souza RGS. Atributos fundamentais dos procedimentos de avaliação. In: Tibério IFLC, Daud-Gallotti RM, Troncon LEA, Martins MA, organizers. Avaliação prática de habilidades clínicas em medicina. São Paulo: Atheneu; 2012. p. 1-11.

16. Rocha SR, Romão GS, Setúbal MSV, Collares CF, Amaral E. Avaliação de habilidades de comunicação em ambiente simulado na formação médica: conceitos, desafios e possibilidades. Rev Bras Educ Med. 2019;43(1 Supl. 1):236-45. doi: 10.1590/1981-5271v43suplemento1-20190154.
17. Dantas AKC. Uso do OSCE como instrumento de avaliação em ginecologia e obstetrícia: percepção dos alunos de medicina da UFRN [dissertation] Natal: Universidade Federal do Rio Grande do Norte; 2018 [access in 13 nov. 2019]. Available from: https://repositorio.ufrn.br/jspui/ handle/123456789/25853.

18. Bandura A. Social Foundations of thought and action: a social cognitive theory. New York: Englewood Cliffs, Prentice Hall; 1986.

19. laochite RT, Costa Filho RA, Matos MM, Sachimbombo KMC. Autoeficácia no campo educacional: revisão das publicações em periódicos brasileiros. Psicol Esc Educ. 2016;20(1):45-54. doi: 10.1590/2175-353920150201922.

20. Bandura A. Swimming against the mainstream: the early years from chilly tributary to transformative mainstream. Behavior Research and Therapy. 2004;42:613-30. doi: 10.1016/ j.brat.2004.02.001.

21. Moreira TC, Ambiel RAM, Nunes MFO. Escala de fontes de autoeficácia para escolha profissional: construção e estudos psicométricos iniciais. Temas Psicol. 2018;26(1):47-60. doi: 10.9788/TP2018.1-03Pt

22. Leonardo FL, Murgo CS, Sena BCS. A ação pedagógica e a autoeficácia docente no ensino superior. EccoS - Rev Cient. 2019;0(48):255-72. doi 10.5585/eccos.n48.8058.

23. Cordeiro GMC, Souza JRS. A importância da afetividade no processo de ensinoaprendizagem. Revista Khora. 2019;6(7) [access in 13 nov. 2019]. Available from: http://www.site.feuc.br/khora/index.php/vol/article/viewFile/165/112.

24. Freire I, Bahia S, Estrela $M$, Amaral A. A dimensão emocional da docência: contributo para a formação de professores. Revista Portuguesa de Pedagogia. 2014;46(2):151-71 [access in 23 sep. 2019]. Available from https://impactum-journals.uc.pt/rppedagogia/article/view/1742.

25. Bahia S, Freire IP, Estrela MT, Amaral A, Espírito Santo JA. The Bologna process and the search for excellence: between rhetoric and reality, the emotional reactions of teachers. Teaching in Higher Education. 2017;22(4):467-82. doi: 10.1080/13562517.2017.1303471.

26. Megale L. Processos avaliativos no curso de medicina: desempenho dos estudantes em relação às competências em pediatria e sua significação pelo docente [thesis]. Belo Horizonte: Universidade Federal de Minas Gerais; 2011 [access in 23 sep. 2019]. Available from: http://hdl.handle. net/1843/EJAO-8JWK7Z.

27. laochite RT. Auto-eficácia de docentes de Educação Física [thesis]. Campinas Universidade Estadual de Campinas; 2007 [access in 20 oct. 2019]. Available from: http://repositorio.unicamp.br/jspui/handle/REPOSIP/252026.

28. Bandura A, Azzi RG, Polydoro S. Teoria Social Cognitiva: conceitos básicos Porto Alegre: Artmed; 2008.

29. Dybowski C, Sehner S, Harendza S. Influence of motivation, self-efficacy and situational factors on the teaching quality of clinical educators. BMC Med Educ. 2017;17(1). doi: 10.1186/s12909-017-0923-2.

30. Polydoro S, Winterstein PJ, Azzi RG, Carmo AP, Venditti R. Escala de autoeficácia do professor de educação física. In: Machado C, Almeida LS, Gonçalves M, Ramalho V, coordenadores. Avaliação psicológica: formas e contextos. Braga: Psiquilíbrios; 2004. p. 330-7.

31. Tschannen-Moran M, Hoy AW. Teacher efficacy: capturing an elusive construct. Teach Teach Educ. 2001;17(7):783-805. doi: 10.1016/s0742 051x(01)00036-1.

32. Bandura A. Self-efficacy: the exercise of control. New York: W. H. Freeman and Company; 1997.

33. Issenberg SB, McGaghie WC, Petrusa ER, Gordon DL, Scalese RJ. Features and uses of high-fidelity medical simulations that lead to effective learning: a BEME systematic review. Med Teach. 2005;27(1):10-28. doi: 10.1080/01421590500046924.

34. Dancey $C P$, Reidy J. Estatística sem matemática para psicologia usando SPSS para Windows. Porto Alegre: Artes Médicas; 2006.

35. Rocha MS. A auto-eficácia docente no ensino superior [thesis]. Campinas Universidade Estadual de Campinas; 2009 [access in 23 sep. 2019]. Available from: http://www.repositorio.unicamp.br/handle/REPOSIP/251766.

36. Azzi RG, Vieira DA, laochite RT, Ferreira LCM, Guerreiro-Casanova DC. Crenças de eficácia pessoal e coletiva. In: Azzi RG, Vieira DA. Crenças de eficácia em contexto educativo. São Paulo: Casa do Psicólogo; 2014. p. 13-24. 
37. Khan KZ, Ramachandran S, Gaunt K, Pushkar P. The Objective Structured Clinical Examination (OSCE): AMEE Guide no 81. Part I: An historical and theoretical perspective. Med Teach. 2013;35(9):1437-46. doi: 10.3109/0142159x.2013.818634.
38. Ribeiro JRC, Bicalho CCF, Onofre MTAS, Noc F. Autoeficácia em professores do ensino superior. Revista de Ensino, Educação e Ciências Humanas. 2019;20(3):319-26. doi: 10.17921/2447-8733.2019v20n3p319-326. 